REFERENCE:

[1] Hughes L, et al. A 5 item version of the Compliance Questionnaire for Rheumatology (CQR5) successfully identifies low adherence to DMARDs. BMC Musculoskelet Disord 2013;14:286.

Disclosure of Interest: None declared

DOI: 10.1136/annrheumdis-2018-eular.4240

\section{AB0218 HIGH LEVEL OF CARTILAGINOUS OLIGOMERIC MATRIX PROTEIN IS ASSOCIATED WITH THE RADIOGRAPHIC PROGRESSION IN PATIENTS WITH EARLY RHEUMATOID ARTHRITIS}

D. Rekalov, D. Nikitina. Rheumatology, Zaporizhzhia Regional Clinical Hospital, Zaporizhzhia, Ukraine

Background: Recent achievements have established that the very first years since the development of the RA are decisive in terms of the progression of the pathological process and the prediction of its remote consequences. This substantiated the need to reflect the heterogeneity and stage of the RA. First of all it concerns the early RA - a time point when the pathological process is in the primary exudative phase and its reversibility is significantly higher, because of not completely formed autoimmune mechanisms and the absence of pannus.

Objectives: Our aim was to establish the relationship between the levels of AntiCitrullinated Peptide Antibody (ACPA), cartilaginous oligomeric matrix protein (COMP) and radiographic progression in patients with early RA

Methods: 75 patients with a diagnosis of early RA were examined, the duration of symptoms was less than 1 year (on average $-4.91 \pm 2.90$ month) that were observed repeatedly on average after 12 months (11.8 \pm 1.2 months). The average age of patients was 46.4 years (from 34 to 62 years), $69.33 \%$ of the examined ones were women, the average duration of the disease at the time of the initial study was 107 days (57-194 days). Immune dysregulation in early RA was confirmed with the evaluation of the key proinflammatory cytokines - ACPA and COMP by the enzyme-linked immunosorbent assay (ELISA) according to the instructions for diagnostic kits. For the testing of articular cartilage lesions and injury of flexor's and extensor's tendons, MRI (1.5 T) and ultrasound diagnostics (US) were performed

Results: Immunological analysis of serum samples of ACPA, COMP was shown the role of these cytokines as prognostic factors of development and prognosis of early RA. The serological features of the obtained data revealed a correlation between the increased concentration of COMP and the progression of joint lesions without ACPA level increase. According to the baseline US data, the tendons of general flexor muscles and extensor brushes were most commonly observed in the examined patients: in general, 52 patients $(69.3 \%)$ and 23 $(30.7 \%)$, respectively. The injury of the tendons of individual fingers (I-V) in the mode of longitudinal and transverse scanning had its own patterns (table 1).

Conclusions:

1. In patients with seronegative (normal ACPA ranges) early RA and high levels of COMP - the highest frequency of erosive and destructive changes can be observed.

2. Injury of the tendons of flexors and extensors determined in major part of the patients with early RA.

Abstract AB0218 - Table 1. Injury of the flexor's and extensor's tendons

\begin{tabular}{|c|c|c|c|c|c|c|}
\hline \multirow[t]{2}{*}{ Fingers } & \multicolumn{3}{|c|}{ Injury of flexor tendons } & \multicolumn{3}{|c|}{ Injury of extensor tendons } \\
\hline & $\begin{array}{l}\text { Totally, } \\
\mathrm{n}(\%)\end{array}$ & $\begin{array}{c}\text { Exudative } \\
\text { tenosinovite, } \\
\mathrm{n}(\%)\end{array}$ & $\begin{array}{c}\text { Exudative - } \\
\text { proliferative } \\
\text { tenosinovitis, } \\
\mathrm{n}(\%)\end{array}$ & $\begin{array}{c}\text { Totally, } \\
\mathrm{n}(\%)\end{array}$ & $\begin{array}{c}\text { Exudative } \\
\text { tenosinovite, } \\
\mathrm{n}(\%)\end{array}$ & $\begin{array}{c}\text { Exudative - } \\
\text { proliferative } \\
\text { tenosinovitis, } \\
\mathrm{n}(\%)\end{array}$ \\
\hline I & $1(1,3)$ & $1(1,3)$ & $0(0,0)$ & $4(5,2)$ & $3(3,9)$ & $1(1,3)$ \\
\hline II & $\begin{array}{c}58 \\
(77,3)\end{array}$ & $52(69,3)$ & $6(8,0)$ & $\begin{array}{c}26 \\
(34,7)\end{array}$ & $24(32,0)$ & $2(2,6)$ \\
\hline III & $\begin{array}{c}36 \\
(48,0)\end{array}$ & $35(46,7)$ & $1(1,3)$ & $\begin{array}{c}18 \\
(24,0)\end{array}$ & $18(24,0)$ & $0(0,0)$ \\
\hline IV & $\begin{array}{c}22 \\
(29,3)\end{array}$ & $20(26,7)$ & $2(2,7)$ & $\begin{array}{c}12 \\
(16,0)\end{array}$ & $9(12,0)$ & $3(3,9)$ \\
\hline V & $\begin{array}{c}13 \\
(17,3) \\
\end{array}$ & $13(17,3)$ & $0(0,0)$ & $6(8,0)$ & $6(8,0)$ & $0(0,0)$ \\
\hline
\end{tabular}

Abstract AB0218 - Table 2. Dynamics of radiographic progression after a 12-month followup

\begin{tabular}{|c|c|c|c|}
\hline \multirow[t]{2}{*}{ Value } & Group 1 & Group 2 & Group 3 \\
\hline & 1 & 2 & 3 \\
\hline ACPA positive, $\%$ & $31 \pm 2,59$ & $\begin{array}{l}18 \pm 1,88 \\
P_{t, 2}<0,01\end{array}$ & $\begin{array}{l}12 \pm 1,17 \\
P_{1.3}<0,01, \\
P_{2,3}<0,01\end{array}$ \\
\hline COMP, U/ & $11,8 \pm 0,73$ & $\begin{array}{l}15,3 \pm 0,62 \\
P_{1.2}<0,01\end{array}$ & $\begin{array}{l}8,4 \pm 0,94 \\
P_{1.3}<0,01, \\
P_{2,3}<0,01\end{array}$ \\
\hline $\begin{array}{l}\text { Frequency of erosions detection at } \\
\text { baseline / after } 12 \text { months, } \%\end{array}$ & $\begin{array}{c}48 / 90 \\
x^{2}=10,93, p<0,01\end{array}$ & $\begin{array}{c}10 / 65 \\
\chi^{2}=10,67, p<0,01\end{array}$ & $\begin{array}{c}10 / 32 \\
\chi^{2}=0,76, p=0,383\end{array}$ \\
\hline $\begin{array}{l}\text { Number of erosions at baseline/ after } \\
12 \text { months, p. }\end{array}$ & $\begin{array}{l}8,04 \pm 0,28 / \\
18,11 \pm 0,71 \\
\mathbb{P}_{w 11}<0,01\end{array}$ & $\begin{array}{l}2,21 \pm 0,23 / \\
15,42 \pm 0,68 \\
P_{\mathbb{P}_{112}<0,001}\end{array}$ & $\begin{array}{c}3,14 \pm 0,42 / \\
7,08 \pm 0,55 \\
\text { р.нд. }\end{array}$ \\
\hline $\begin{array}{l}\text { Frequency of synovitis andtendnitis } \\
\text { detectionat baseline / a fter } 12 \\
\text { months, } \%\end{array}$ & $\begin{array}{c}51 / 81 \\
\gamma^{2}=4,61, \mathrm{p}<0,05\end{array}$ & $\begin{array}{c}32 / 71 \\
x^{2}=4,9, p<0,05\end{array}$ & $\begin{array}{c}21 / 36 \\
x^{3}=0,18, \mathrm{p}=0,676\end{array}$ \\
\hline $\begin{array}{l}\text { Note: } P_{1-2} \text { - the level of signi } \\
\text { groups. }\end{array}$ & ce of differences & irwise compariso & the corresponding \\
\hline
\end{tabular}

\section{REFERENCES:}

[1] Alasaarela E, et al. Evaluation of humoral head erosions in RA: a comparison of US MRI, CT and plain radiography. Br J Rheumatol 1998;37:1152-

[2] Bang $\mathrm{H}$, et al. Mutation and citrullination modifies vimentin to a novel auto antigen for RA. Arthritis Rheum 2007;56:2503-2511.

Disclosure of Interest: None declared DOI: 10.1136/annrheumdis-2018-eular.2398

\section{AB0219 IMPACT OF EARLY DIAGNOSIS ON LONG-TERM EFFECTIVENESS OF FIRST-LINE ANTI-TNF-ALPHA TREATMENT IN RHEUMATOID ARTHRITISPATIENTS}

D. Capocotta, S. Montalbano, D. Lubrano, E. Tirri. Rheumatology Unit, San Giovanni Bosco Hospital, Naples, Italy

Objectives: Aim of this work was to evaluate effectiveness and drug persistence of anti-tumour necrosis factor (TNF)-alpha therapies in early and late diagnosed rheumatoid arthritis (RA) patients naïve for biological disease-modifying antirheumatic drug (bDMARD) use.

Methods: Baseline and follow-up (FU) charts RA patients with disease onset late than 2002 and access to rheumatology care between January 2007 and Decembe 2016 were reviewed until December 2017. All patients fulfilled 2010 ACR/EULAR classification criteria. At baseline, demographic, anamnestic and serological characteristics were collected. Based on lag time between onset of symptoms and definite diagnosis, RA patients were categorised into two groups: early diagnosed (less than 12 months) and late diagnosed (more than 12 months). Disease activity and treatment response were assessed every three months by Simplified Disease Activity Index (SDAI). Anti-TNF-alpha survival was defined as the length of time from initation to discontinuation of therapy due to loss of effectiveness over time. It was examined using Kaplan-Meier survival analysis.

Results: One hundred and fifteen RA patients (86.1\% females, mean age 59.4$)$ were included. The median disease duration between onset of symptoms and diagnosis was 25 months. ${ }^{20-43} 68$ patients (59.1\%) were labelled as early diagnosed and $47(40.9 \%)$ as late diagnosed. At baseline, no differences were found in age, gender, smoking habits, body mass index, and rheumatoid factor positivity. The most frequently used first-line anti-TNF drug was etanercept $(30.4 \%)$, followed by adalimumab (20\%), golimumab (18.3\%), infliximab (16.5\%), and certolizumab (14.8\%). All patients received anti-TNF-alpha therapy in combination with csDMARD (methotrexate or leflunomide). Average steroid dosage was $5 \mathrm{mg} / \mathrm{day}$ of prednisone (or its equivalent) over time. The median time to initation of any antiTNF-alpha treatment after definite diagnosis was 18 months. ${ }^{6-30}$ Kaplan-Meier analysis showed a lower anti-TNF-alpha discontinuation rate for early diagnosed RA patients than late diagnosed (9 year retention rate of $29.5 \%$ and $12.7 \%$, respectively; $p=0.0049$ ) (figure 1 ). 